Saint Louis University School of Law

Scholarship Commons

All Faculty Scholarship

2016

\title{
Gig Economy: Settlements Leave Labor Issues Unsettled
}

Miriam A. Cherry

Saint Louis University School of Law

Follow this and additional works at: https://scholarship.law.slu.edu/faculty

Part of the Labor and Employment Law Commons

\section{Recommended Citation}

Cherry, Miriam A., Gig Economy: Settlements Leave Labor Issues Unsettled (May 5, 2016).

This Article is brought to you for free and open access by Scholarship Commons. It has been accepted for inclusion in All Faculty Scholarship by an authorized administrator of Scholarship Commons. For more information, please contact erika.cohn@slu.edu, ingah.daviscrawford@slu.edu. 


\section{Gig Economy: Settlements Leave Labor Issues Unsettled}

Law360, New York (May 5, 2016, 10:26 AM ET) -- Companies in the sharing economy continue to encounter legal challenges to their business models and employment practices. Just last month, Uber Technologies Inc. settled two closely watched worker classification class actions for as much as $\$ 100$ million. This Law360 Expert Analysis series explores how the sharing economy could work better, from the points of view of a former chief economist for the U.S. Department of Commerce, the general counsel of a New York City taxicab advocacy organization, an employment lawyer and an employment law professor.

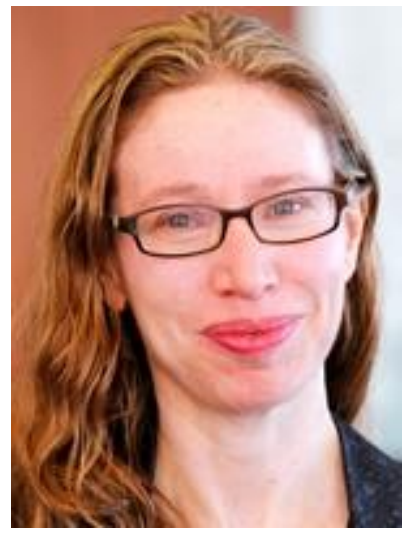

Miriam A. Cherry

Over the past few years, workers in the on-demand economy have filed numerous lawsuits in an attempt to lay claim to the benefits associated with employment status. In response, on-demand companies have countered that these workers, who may be part-time, contingent and set their own schedules, look more like independent contractors. In a recent paper that is part of a special issue of the Comparative Labor Law and Policy Journal, I created the below chart mapping these various litigations. The workers in these cases are performing jobs as diverse as driving, delivery services, errands, home repairs and various computer tasks. As noted elsewhere, the question of employee status has implications for collection of minimum wage, the ability to unionize, proper tax withholding, and the coverage of worker's compensation and unemployment insurance. 


\begin{tabular}{|c|c|c|c|c|}
\hline Casename & Case No. & Jurisdiction & $\begin{array}{l}\text { Gravamen of } \\
\text { Litigation }\end{array}$ & Status \\
\hline $\begin{array}{l}\text { Agruss v. } \\
\text { Homejoy }\end{array}$ & $1: 15$-cv-00767 & N.D. III. & $\begin{array}{l}\text { FLSA; Home } \\
\text { handyperson } \\
\text { services }\end{array}$ & $\begin{array}{c}\text { Class claims } \\
\text { dismissed without } \\
\text { prejudice on } \\
05 / 05 / 2015 ; \\
\text { Homejoy ceased } \\
\text { operations. }\end{array}$ \\
\hline $\begin{array}{c}\text { Shardae } \\
\text { Bennett v. } \\
\text { Wash. Io, } \\
\text { Inc. }\end{array}$ & BC603067 & $\begin{array}{c}\text { CA } \\
\text { Superior } \\
\text { Court - } \\
\text { Los } \\
\text { Angeles } \\
\text { County }\end{array}$ & $\begin{array}{l}\text { Violation of } \\
\text { Cal. Labor } \\
\text { Code } \\
\text { Sect. 226.8 }\end{array}$ & $\begin{array}{l}\text { Class Action } \\
\text { Complaint filed } \\
12 / 8 / 2015 \text {. No } \\
\text { response filed to } \\
\text { date. }\end{array}$ \\
\hline $\begin{array}{c}\text { Cobarruviaz } \\
\text { v. } \\
\text { Maplebear }\end{array}$ & $\begin{array}{c}\text { 3:15-cv-00697- } \\
\text { EMC } \\
2015 \mathrm{WL} \\
694112\end{array}$ & N.D. Cal. & $\begin{array}{l}\text { FLSA; Grocery } \\
\text { delivery service } \\
\text { app }\end{array}$ & $\begin{array}{c}\text { Court granted } \\
\text { Instacart's } \\
\text { (Maplebear's) } \\
\text { motion to compel } \\
\text { arbitration on an } \\
\text { individual basis } \\
\text { granted except } \\
\text { for the Private } \\
\text { Attorney General } \\
\text { (PAGA) } \\
\text { representative } \\
\text { claim. }\end{array}$ \\
\hline $\begin{array}{c}\text { Cotter v. } \\
\text { Lyft }\end{array}$ & $\begin{array}{c}\text { 3:13-cv-04065- } \\
\text { VC }\end{array}$ & N.D. Cal. & $\begin{array}{c}\text { Employee } \\
\text { benefits, cost } \\
\text { reimbursements } \\
; \\
\text { Ridesharing/dri } \\
\text { ver app }\end{array}$ & $\begin{array}{l}\text { Settlement } \\
\text { agreement for } \\
\$ 12 \text { million } \\
\text { agreed to on } \\
1 / 27 / 16 \text {. Due } \\
\text { process rights on } \\
\text { termination also } \\
\text { granted as part of } \\
\text { settlement. }\end{array}$ \\
\hline $\begin{array}{c}\text { Ehret v. } \\
\text { Uber }\end{array}$ & $\begin{array}{l}\text { 3:14-cv-00113- } \\
\text { EMC } \\
\text { 68 F.Supp.3d } \\
1121\end{array}$ & N.D. Cal. & $\begin{array}{c}\text { Employee } \\
\text { benefits, cost } \\
\text { reimbursements } \\
\text {; Ridesharing/ } \\
\text { driver app }\end{array}$ & $\begin{array}{l}\text { Motion to Certify } \\
\text { Class \& } \\
\text { Consolidate } \\
\text { Cases granted } \\
10 / 22 / 15 \text {; Case } \\
\text { management } \\
\text { conference set for } \\
1 / 28 / 16 \text {. }\end{array}$ \\
\hline $\begin{array}{l}\text { Jeung et al. } \\
\text { v. Yelp }\end{array}$ & $\begin{array}{c}\text { 3:15-cv-02228- } \\
\text { RS } \\
2015 \mathrm{WL} \\
4776424\end{array}$ & N.D. Cal. & $\begin{array}{c}\text { Unjust } \\
\text { enrichment / } \\
\text { Restitution for } \\
\text { time spent } \\
\text { writing online } \\
\text { reviews }\end{array}$ & $\begin{array}{c}\text { Case dismissed } \\
\text { on } 9 / 29 / 15 .\end{array}$ \\
\hline $\begin{array}{l}\text { Levin v. Try } \\
\text { Caviar }\end{array}$ & $\begin{array}{c}3: 15-\mathrm{cv}-01285 \\
2015 \mathrm{WL} \\
7529649\end{array}$ & N.D. Cal. & $\begin{array}{c}\text { FLSA; Grocery } \\
\text { delivery service } \\
\text { app }\end{array}$ & $\begin{array}{l}\text { Individual claims } \\
\text { sent to } \\
\text { arbitration; } \\
\text { Awaiting further } \\
\text { briefing on } \\
\text { Plaintiff's PAGA } \\
\text { claims. }\end{array}$ \\
\hline
\end{tabular}




\begin{tabular}{|c|c|c|c|c|}
\hline $\begin{array}{l}\text { Mohamed v. } \\
\text { Uber, a/k/a } \\
\text { In Re Uber } \\
\text { FCRA } \\
\text { Litigation }\end{array}$ & $\begin{array}{c}\text { 3:14-cv-05200- } \\
\text { EMC } \\
\text { Consolidated } \\
\frac{\text { with }}{14-c v-05241-} \\
\text { EMC } \\
\text { 15-cv-03009- } \\
\text { EMC } \\
109 \text { F.Supp. 3d } \\
1185 \\
\end{array}$ & N.D. Cal. & $\begin{array}{c}\text { Employee } \\
\text { benefits, cost } \\
\text { reimbursements } \\
\text {; Ridesharing/ } \\
\text { driver app }\end{array}$ & $\begin{array}{c}\text { Class } \\
\text { Certification \& } \\
\text { Motion to } \\
\text { Consolidate } \\
\text { Cases granted } \\
10 / 22 / 15 ; \\
\text { Defendant's } \\
\text { motion to compel } \\
\text { arbitration denied }\end{array}$ \\
\hline $\begin{array}{l}\text { O'Connor v. }_{\text {Uber }} \\
\text { Und }\end{array}$ & $\begin{array}{c}\text { 3:13-cv-03826- } \\
\text { EMC }\end{array}$ & N.D. Cal. & $\begin{array}{c}\text { Employee } \\
\text { benefits, Cost } \\
\text { reimbursements } \\
\text {; Overtime } \\
\text { under FSLA; } \\
\text { Ridesharing/ } \\
\text { Driver app }\end{array}$ & $\begin{array}{l}\text { Settlement } \\
\text { agreement for } \\
\$ 100 \text { million } \\
\text { agreed to on } \\
4 / 21 / 16 \text {. Due } \\
\text { process rights on } \\
\text { termination also } \\
\text { granted. }\end{array}$ \\
\hline $\begin{array}{l}\text { Otey v. } \\
\text { Crowdflowe } \\
\text { r }\end{array}$ & $\begin{array}{c}\text { 3:12-cv-05524- } \\
\text { JST }\end{array}$ & N.D. Cal. & $\begin{array}{c}\text { FLSA; } \\
\text { Crowdwork }\end{array}$ & $\begin{array}{l}\text { Settlement } \\
\text { agreement } \\
\text { approved by the } \\
\text { Court. Parties } \\
\text { now seeking to } \\
\text { amend the } \\
\text { settlement; Court } \\
\text { denied Motion to } \\
\text { Modify. }\end{array}$ \\
\hline $\begin{array}{l}\text { Rojas- } \\
\text { Lozano v. } \\
\text { Google, Inc. }\end{array}$ & $\begin{array}{c}\text { 3:15-cv-03751- } \\
\text { JSC } \\
\text { 2015 WL } \\
4779245\end{array}$ & N.D. Cal. & $\begin{array}{l}\text { FLSA or Unjust } \\
\text { Enrichment / } \\
\text { Word } \\
\text { transcription } \\
\text { ("Captchas") or } \\
\text { identification } \\
\text { for Google } \\
\text { Earth (without } \\
\text { pay) }\end{array}$ & $\begin{array}{l}\text { Motion to } \\
\text { Dismiss filed by } \\
\text { Google heard } \\
\text { 12/15; Court has } \\
\text { requested } \\
\text { supplemental } \\
\text { briefing. }\end{array}$ \\
\hline $\begin{array}{c}\text { Sherry } \\
\text { Singer et al } \\
\text { v. } \\
\text { Postmates, } \\
\text { Inc. }\end{array}$ & $\begin{array}{c}4: 15-\mathrm{cv}-01284 \\
\text { JSW }\end{array}$ & $\begin{array}{l}\text { U.S. } \\
\text { District } \\
\text { Court } \\
\text { California } \\
\text { Northern } \\
\text { District }\end{array}$ & $\begin{array}{l}\text { Violation of } \\
\text { FLSA and Cal. } \\
\text { Labor Code } \\
\text { Sect. } 226.8 \text { et } \\
\text { seq. }\end{array}$ & $\begin{array}{c}\text { Class Action } \\
\text { Complaint filed } \\
3 / 19 / 2015 \text {. } \\
\text { Motion for } \\
\text { Partial Summ. } \\
\text { Judgment filed by } \\
\text { Defendant } 6 / 2015\end{array}$ \\
\hline $\begin{array}{l}\text { Andrew Tan } \\
\text { v. Grubhub, } \\
\text { Inc. }\end{array}$ & $3: 15-\mathrm{cv}-05128$ & N.D. Cal. & $\begin{array}{c}\text { Violation of } \\
\text { Cal. Labor } \\
\text { Code; } \\
\text { Restaurant/Food } \\
\text { delivery } \\
\text { website/app }\end{array}$ & $\begin{array}{l}\text { Removed from } \\
\text { state court. First } \\
\text { Amended } \\
\text { Complaint filed } \\
12 / 15 / 16 .\end{array}$ \\
\hline $\begin{array}{l}\text { Zenelaj et } \\
\text { al. v. } \\
\text { Handybook, } \\
\text { Inc. }\end{array}$ & $\begin{array}{c}\text { 3:14-cv-05449- } \\
\text { THE } \\
109 \text { F.Supp.3d } \\
125\end{array}$ & N.D. Cal. & $\begin{array}{l}\text { FLSA; Home } \\
\text { handyperson } \\
\text { services }\end{array}$ & $\begin{array}{l}\text { Parties mediated } \\
\text { the dispute } \\
\text { without success. } \\
\text { Case is headed } \\
\text { toward } \\
\text { arbitration. }\end{array}$ \\
\hline
\end{tabular}

Commentators following these misclassification lawsuits have been anxiously awaiting the outcome of the O'Connor v. Uber litigation. With over 400,000 drivers consolidated into a class action, and a jury trial scheduled for June 2016 in the Northern District of California, many viewed this case as pivotal. The hope was that the case would provide guidelines for characterizing workers in the on-demand economy. 
As others have noted, there are arguments for both of these classifications. On the one hand, crowdworkers have considerable flexibility to set their own schedules and can sign on and off the app more readily than do real workers in a traditional environment who work a set shift or who are otherwise tethered to a workplace desk or factory floor. Crowdworkers also use their own cellular telephones, computer equipment, Internet connections or, in the case of Uber, cars, as the instrumentalities of work. Further, end user license agreements contractually label crowdworkers as "independent contractors."

On the other hand, many factors lean toward an employment relationship. Control may be high, given that companies like Uber use customer ratings to maintain almost a constant surveillance over workers, with consumers deputized to manage the workforce. Many on-demand companies spend a great deal of time and effort to implement quality control policies. With low-skilled crowdwork, the opportunity for entrepreneurship, and with it risk-and-reward, is barely, if at all, present. The terminology in a EULA is far from dispositive, as such online contracts are known to be extremely one-sided and are construed against the drafter. The possibility for exploitation is high, and low-skilled workers are those that are most in need of Fair Labor Standards Act protection.

This left Judge Edward M. Chen in the Northern District of California with a malleable legal test, and a set of facts that fit neither classification clearly. The confusion was evident in his decision to send the case to be heard in front of a jury, scheduled for June 2016. However, on April 21, 2016, O'Connor v. Uber settled with a proposed $\$ 100$ million payment to the drivers. Additional terms in the settlement make it clear that the company can no longer "deactivate" drivers from their accounts without an arbitrator ruling on their grievance.

Disappointingly, the important issues that were at stake in the litigation still remain unresolved. The issue about employee status was not decided. While the amount of damages in the settlement sounds large, after deducting the percentage for the plaintiffs' attorneys and then splitting the amount over 400,000 drivers, some workers will only recover nominal payments.

Should the court approve the settlement, Uber will likely avoid a finding of employee status in this case. However, there is no guarantee that the Internal Revenue Service, the National Labor Relations Board or another governmental regulator will not later determine - on its own accord - that these workers are employees or that these platforms are employers. For an argument that the NLRB will find the drivers to be employees, check out Alan Hyde's argument.

Perhaps what this settlement shows us, more than anything, is the weakness of regulating labor standards through the method of private attorneys bringing class actions. When large monetary settlements are offered, and attorneys are working on contingency fees, perhaps it would be inevitable that the question of worker status would fall by the wayside.

Perhaps more important than these legal maneuvers is the issue of work changing in response to technological restructuring. These debates are not new. In my article, I argue that we are currently experiencing a far-reaching digital transformation of work. Other commentators have noted that in the past few decades, "knowledge work" was changing the typical life cycle model of work. Rather than learn a few company-specific skills, workers were prized for learning more generally about their field of endeavor. Rather than working at one company their whole life and being promoted from within, many workers were finding success by moving between companies. Instead of promising job security, employers were promising enhanced training and networking opportunities. 
Ideally, technology should be a tool to assist workers, making work easier and safer while boosting productivity for workers and convenience for consumers. The logical outcome of technology should be less work hours, more flexibility, better pay and overall more satisfying jobs. One would believe that "bad jobs" - those that are dirty, dangerous and low-paying would increasingly become automated. The work week should decrease and the gains from productivity should raise the average worker's standard of living. Training and knowledge, as noted above, would be extremely important.

Unfortunately to date, that is not the story of work in the gig economy. The changes we are seeing include the growth of automatic management, such as management by algorithm, and a move toward ever more precarious work, exemplified by the idea of needing to compete for individual and eversmaller gigs or tasks through a platform. In fact, the last few years have seen rising economic inequality, a bimodal distribution of good jobs and income, and bad jobs and low pay, with no reduction in the average work week. Although this is a complex phenomenon, it is safe to say that the productivity gains of technology are being unevenly distributed.

But this result is not inevitable. Technology should help us improve work systems and work design, not facilitate a race to the bottom of deskilling of work and lowered wages. So the real question with crowdwork and the on-demand economy is not whether the workers fall into a particular doctrinal category of "employee" or "independent contractor," as the current legal cases have structured the question, and which still remain unsettled after O'Connor v. Uber. Rather we should be concerned about whether the crowdwork model that the on-demand economy moves us into is a sustainable and desirable future of work with "good" jobs. If it is not doing that, we should think beyond the doctrinal categories to ask how the gains of technology can be distributed in a way that result in good work experiences.

-By Miriam A. Cherry, Saint Louis University School of Law

Miriam Cherry is a professor of law at Saint Louis University.

The opinions expressed are those of the author(s) and do not necessarily reflect the views of the firm, its clients, or Portfolio Media Inc., or any of its or their respective affiliates. This article is for general information purposes and is not intended to be and should not be taken as legal advice.

All Content (C) 2003-2016, Portfolio Media, Inc. 